\title{
CECÍlIA MEIRELES E AS POSSIBILIDADES DE TURISMO NO BRASIL
}

\section{CECILIA MEIRELES AND TOURISM POSSIBILITIES IN BRAZIL}

\author{
Luís Antônio Contatori Romano"
}

Resumo: Entre 1941 e 1942, Cecília Meireles edita, para o Departamento de Imprensa e Propaganda (DIP), do Governo Vargas, a revista Travel in Brazil, publicação em inglês que visava divulgar no exterior, especialmente nos Estados Unidos, as possibilidades de turismo no Brasil. A poeta convida a colaborar na revista autores como Mário de Andrade, Manuel Bandeira, Paulo Rónai, Sérgio Buarque de Hollanda, Tasso da Silveira, José Lins do Rego, Rachel de Queiroz entre outros, além de haver muitos textos de autoria da própria Cecília. Cecília Meireles não editava uma revista para o mero turista, mas para o viajante contemplativo e curioso em relação às complexidades culturais do lugar que se dispõe a visitar.

Palavras-Chave: Cecília Meireles; Travel in Brazil; literatura de viagens.

Aвstract: Between 1941 and 1942, Cecilia Meireles edits to the Department of Press and Propaganda (DIP), of the Vargas government, the magazine Travel in Brazil, published in English and addressed to the dissemination abroad, especially in the United States, the possibilities of tourism in Brazil. The poet invites authors to collaborate in the magazine as Mário de Andrade, Manuel Bandeira, Paulo Rónai, Sérgio Buarque de Hollanda, Tasso da Silveira, José Lins do Rego, Rachel de Queiroz among others, and there are many texts written by Cecilia yourself. Cecilia Meireles not edited a magazine for to the mere tourist, but to the contemplative and curious traveler with respect to the cultural complexities of the place of visit.

KEYwords: Cecília Meireles; Travel in Brazil; travel literature.

\footnotetext{
"Doutor em Teoria e História Literária pela Unicamp, Pós-Doutor em Literatura Brasileira pelo IEB-USP. Professor de Estudos Literários na Unifesspa e Diretor-Geral do Instituto de Linguística, Letras e Artes (ILLA) da Unifesspa. Pesquisador Produtividade (PQ2) do CNPq.Email:contatori_romano@yahoo.com.br
} 
Desde suas crônicas jornalísticas sobre temas de educação, iniciadas a partir da década de 1930, Cecília Meireles demonstra interesse pela viagem como atividade formadora do sujeito e capaz de fomentar a compreensão entre os povos. Na crônica "Fraternidade" (Meireles, 2001), publicada no jornal carioca Diário de Notícias, em 23 de janeiro de 1932, Cecília trata de uma exposição de artesanato mexicano no Rio de Janeiro, fomentada pelo então embaixador do México no Brasil, o poeta Alfonso Reyes. Exposição essa que, de acordo com Cecília Meireles, contribuiria para que os jovens estudantes olhassem para além das fronteiras de sua própria geografia. Mais tarde, já no início do decênio de 1940, a poeta começa a esboçar em crônicas que tematizam suas próprias experiências de viagem concepções do turista e do viajante contemporâneo. $O$ turista seria aquele que transita entre espaços estrangeiros, buscando percorrer o maior número possível e apropriar-se deles por meio da miniaturização fotográfica. $O$ viajante concentra seu olhar em determinados objetos, procura observá-los mais demorada e detidamente e põe em movimento uma série de relações intertextuais, derivadas de leituras prévias, mapas, obras de arte, memórias de infância, outras viagens... O viajante ceciliano é um contemplador, que busca conhecer e relacionar informações e imagens. Pode inserir-se na tradição de viajantes eruditos como Michel de Montaigne (1986), que no percurso que realizou entre 1580 e 1581, por França, Alemanha, Suíça e Itália, registrou em seu diário sentir falta de três coisas: de um cozinheiro que aprendesse sobre os pratos do percurso, para que pudesse reexperimentá-los ao retornar à sua propriedade na Aquitânia; de eruditos companheiros locais, que pudessem instruí-lo sobre cada cidade percorrida, sua cultura e história, e de ter um exemplar da Cosmografia Universal (1552), de Münster, compêndio da cultura universal da época. Ou na tradição de um Goethe que, em viagem à Itália entre 1786 e 1788, dedica um demorado tempo a fim de registrar esboços de rostos de pessoas, paisagens e objetos vistos durante o percurso. $\mathrm{Ou}$, ainda, de Eugène Delacroix que, durante sua viagem pelo Norte da África em 1832, preenche inúmeros cadernos com impressões sobre a cultura árabe, comentários e desenhos de cenas cotidianas, experiências de estranhamento e de se sentir observado como estranho em terras do Magreb.

As distinções esboçadas por Cecília Meireles (1999) em crônicas como "Roma, Turistas e Viajantes", de 1953, podem nos conduzir às reflexões apresentadas, décadas mais tarde, por Fernando Cristóvão (2002), no ensaio "Para uma Teoria da Literatura de Viagens". Esse crítico português propõe cinco acepções de viajantes: peregrinos, comerciantes, desbravadores vinculados ao expansionismo (religioso, colonial ou científico), eruditos e viajantes imaginários. Cristóvão considera, porém, que a Literatura de Viagens, produto dos relatos desses viajantes e da relação entre editores e leitores, tenha se esgotado em meados do século XIX em função da modernização e expansão dos meios de comunicação e transporte, que esquadrinharam o mundo tornando-o completamente conhecido, assim como do 
desenvolvimento dos serviços de hotelaria e de turismo. Fatores esses que permitiram um acesso de um número imensamente maior de pessoas à viagem, proporcionando uma crescente difusão de relatos e imagens de espaços e culturas estrangeiras, o que conduziu à banalização da Literatura de Viagens. Expansão de transportes, difusão de informações e crescimento da oferta de serviços que, na visão de Enzensberger (1985), no ensaio "Uma Teoria do Turismo", de 1958, foram condições para a transformação da viagem quase sempre dificultosa e desagradável - de meio para atingir outros espaços geográficos em fim em si mesma, o que caracteriza a viagem turística. Os navegadores renascentistas a serviço das Coroas de Espanha e Portugal não viajavam pelo "prazer da aventura", a eles atribuído pelo espírito romântico, mas cumpriam funções de Estado. Se jovens aristocratas britânicos faziam, já no século XVII, o Gran Tour pela Europa Continental para conhecerem outras cortes, se por razões de saúde surgiram as estações termais e os balneários marítimos, paulatinamente, o que passará pela mediação do espírito romântico, viajar a cidades de tradição histórica e cultural da Europa Continental, veranear por hotéis em estações balneárias ou termais torna-se uma expressão de liberdade e um fim em si mesmo. Mas, quando o objetivo do turista passa a ser um afastamento temporário das relações sociais e de trabalho cotidianas, cuja liquidez e ritmo se aceleram no contexto da sociedade capitalista, a viagem turística, paradoxalmente, passa a reproduzir o modo de produção industrial, estruturado em regras, montagem e fabricação em série, como considera Enzensberger (1985). Dessa forma, o desenvolvimento dos serviços turísticos regulamenta metas de viagem (os sights) difundidos especialmente pelos guias de viagem; a viagem é montada e organizada cronologicamente na forma de um roteiro que direciona o turista a percorrer os sights e, para barateá-la, é necessário que seja serializada, assumindo a forma das viagens em grupo ou "pacotes" turísticos. Não sem razão, esses foram criados na Inglaterrra, por Thomas Cook, no início do século XIX, o país que produziu a Revolução Industrial no século anterior.

Não obstante se inserir na tradição de viajantes contemplativos, eruditos e que punham em questão a alteridade, como Montaigne, Goethe e Delacroix, Cecília Meireles é contemporânea das facilidades da viagem turística: viagens aéreas, navios transatlânticos e trens que unem países e continentes, guias de viagem, serviços de hotelaria e de restaurantes. Somente podemos aproximar Cecília Meireles da acepção de viajante de erudição, proposta por Cristóvão, ultrapassando as delimitações temporais estabelecidas pelo crítico. Das várias viagens que fez pelo Brasil e ao exterior entre as décadas de 1930 e 1960, Cecília Meireles deixou inúmeros registros, em poemas e, principalmente, em crônicas, que contribuem para renovar a Literatura de Viagens na Contemporaneidade. Mas o valor das crônicas de viagem cecilianas não advém da novidade dos locais visitados, das dificuldades dos deslocamentos e do restrito número de testemunhas - condições essas que para Cristóvão sustentaram o interesse pela Literatura de Viagens tradicional. O interesse 
que essas crônicas ainda pode despertar nos leitores advém do olhar contemplativo, lírico e, por vezes, efabulador dessa poeta-viajante, das relações intertextuais que põe em movimento em cada lugar que visita, evocando poetas, livros, pinturas, informações históricas, folclore... e da linguagem limítrofe entre a prosa e a poesia com a qual Cecília retranscreve suas experiências de viagem.

É sob a perspectiva de uma lírica e erudita viajante contemporânea que Cecília Meireles procura mostrar o Brasil para estrangeiros na revista Travel in Brazil, que edita para o Departamento de Imprensa e Propaganda (DIP), do Estado Novo de Vargas. Essa revista foi uma publicação em inglês ${ }^{1}$, voltada para divulgar principalmente nos Estados Unidos as possibilidades de turismo no Brasil, teve quatro números lançados em 1941 e outros quatro, em 1942, todos ricamente ilustrados com fotografias em preto e branco. A poeta havia, até então, realizado duas viagens ao exterior. A primeira, a Portugal, em 1934, em companhia do artista plástico Fernando Correia Dias, seu primeiro marido. A segunda, entre maio e agosto de 1940, aos Estados Unidos, a convite da Universidade do Texas, para ministrar um curso de Literatura e Cultura Brasileiras, viagem que se estendeu até o México, em companhia de seu segundo marido, Professor Heitor Grillo. Experiências de

\footnotetext{
${ }^{1}$ Os fragmentos de textos publicados na revista Travel in Brazil serão citados neste artigo em traduções para o português por mim propostas, a partir do projeto de pesquisa que venho desenvolvendo, financiado por CNPq-MCTI/Universal/2014, com vigência de 2014 a 2017, intitulado "O Brasil para Estrangeiros em 1941-1942: Uma Versão Bilíngue da Revista Travel in Brazil, Editada por Cecília Meireles".
}

viajante, pouco acessíveis naqueles tempos, e curiosidade pela cultura do Outro que talvez tenham motivado Cecília Meireles a aceitar o convite do DIP. Coerente com o espírito interdisciplinar de Cecília, os textos publicados nessa revista revelam grande diversificação temática e de colaboradores. Alguns tendem a certo nacionalismo ingênuo, como o de José Lins do Rego (Travel in Brazil, $\left.\mathrm{n}^{\circ} 2,1942\right)^{2}$, que, ao apresentar a Bahia como exemplo da cordialidade dos brasileiros, recorre a bordões como "Cristo nasceu na Bahia" ou "Deus é brasileiro"; o de Rachel de Queiroz (TB, ${ }^{\circ} 3,1941$ ), que, ao tratar dos esforços do homem do Nordeste para vencer as condições naturais adversas, enfatiza o empenho do governo para a construção de açudes visando resolver o problema da seca na região; ou o de Menotti Del Picchia (TB, $\mathrm{n}^{\circ}$ 3, 1941) sobre o turismo em São Paulo, exaltando seus bairros, avenidas, estádios, fonte luminosa, indústrias, monumentos, museus, centros de pesquisas e parques; o Parque do Ipiranga, afirma, "sozinho seria suficiente para fazer de São Paulo a Meca dos turistas"! Outros abordam interessantes aspectos marginais da cultura brasileira, como, em tom romântico, faz Basílio de Magalhães (TB, $\mathrm{n}^{\circ}$ 4, 1942), sobre a vida dos tropeiros, ressaltando aspectos de sua alimentação, indumentária, animais de carga e importância deles para o comércio no interior do Brasil antes da chegada das estradas de ferro, que teriam posto fim à "aventura poética" das tropas; ou os diferentes modelos de casas dos caboclos do interior do Brasil, em texto de Ângelo Murgel (TB, nº 3, 1941). Há um artigo assinado por

\footnotetext{
${ }^{2} \mathrm{~A}$ partir das próximas menções à revista Travel in Brazil como fonte bibliográfica utilizarei a sigla TB.
} 
Heitor Grillo (TB, $n^{\circ} 2$, 1941) sobre as possibilidades industriais e decorativas da grande variedade de orquídeas brasileiras; outro sobre as pesquisas científicas desenvolvidas pelo Instituto Oswaldo Cruz, assinado por Oswaldo Frota Pessoa (TB, nº 2, 1942). Há também artigo de Aloisio Napoleão (TB, $n^{\circ}$ 1, 1942), sobre a história da construção do Palácio do Itamaraty, no Rio de Janeiro, de seus bailes e recepções famosos, texto com laivos de grandezas aristocráticas periféricas.

A diversidade de artigos reflete, por um lado, a necessidade de contemporizar com as intenções propagandísticas do Governo Vargas e de seu Departamento de Imprensa e Propaganda; por outro, dentro do que lhe parecia possível, Cecília Meireles procura editar textos de escritores e intelectuais mais afinados com seu próprio pensamento, como deixa claro na correspondência com Mário de Andrade, quando lhe solicita artigos e afirma que gostaria de evitar "invasão de colaboradores". Além disso, a variedade temática, em certo sentido, reflete também uma visão ampla do turismo. Em linhas gerais, o turista, ou viajante, estrangeiro que nos poderia visitar e a quem ela dirige a revista é alguém que se interessaria pela cultura do Outro e não apenas em passear diante de paisagens e monumentos. Daí, a variedade de artigos com descrições tão minuciosas de aspectos da música e das artes brasileiras, museus, igrejas, paisagens urbanas, cidades de veraneio, História do Brasil, festas populares, bonecas artesanais, além de centros de pesquisas científicas.

Lendo-se a correspondência entre Cecília Meireles e Mário de Andrade, é possível observar o esforço que a poeta fazia para conciliar os propósitos autoritários do Governo Vargas em seu intento de divulgar um Brasil "embranquecido" e "civilizado" no exterior e as próprias concepções da poeta. Essa correspondência foi organizada pelo Instituto de Estudos Brasileiros da Universidade de São Paulo (IEB-USP), sob supervisão de Telê Ancona Lopez, e publicada pela Nova Fronteira em 1996, com o título Cecília e Mário, volume que traz também o estudo e a antologia que Cecília organizou sobre a poesia de seu amigo modernista.

Em carta datada de 7 de março de 1941, Cecília Meireles agradece a Mário de Andrade um artigo que este lhe enviara para o primeiro número da revista Travel in Brazil, que acabava de ser editado; e pede outro texto ao amigo. $\mathrm{O}$ artigo, vertido para o inglês, ao que se sabe, pela própria poeta, intitula-se "Música Brasileira" (TB, nº 1, 1941). Nele, Mário de Andrade considera a música como uma das expressões mais características do Brasil. Trata das músicas dos indígenas e dos negros, aborda as formas híbridas da modinha, do lundu e o abrasileiramento da ópera europeia por Carlos Gomes, até chegar às propostas nacionalistas de Vila Lobos apresentadas durante a Semana de Arte Moderna de 1922.

Em carta datada de 21 de março de 1941, Mário de Andrade responde a Cecília, anunciando um artigo sobre os afrescos da Capela da família de Portinari, em Brodowski:

Cecília Meireles, estou chegando de Brodowski com um assunto-mãe na mão e encontro a sua carta. Até dia 31 lhe mandarei com o devido rancho de fotografias, um 
artigo (duas páginas ofício datilografadas, não é isso?) sobre a capela que o Portinari acaba de decorar na residência da família dele em Brodowski, acha bom o assunto? Com a voga Portinari nos States e a admirável força do trabalho que ele acaba de realizar, acredito que se poderá fazer uma página legível para o Travel in Brazil. Aliás não recebi a revista, furto apetitoso de correio, e lhe peço tentar o envio de apenas mais um número. Não pra que julgue dele mas pra meu governo.

Me lembro meio sim meio não que você me falara apenas em artigos sobre música e folclore, não era mesmo? Folclore com fotografias e sem o indispensável comparecimento dos nossos irmãos em S. Benedito, é quase impossível e provavelmente Travel in Brazil obedece a essa lei diplomática que afirma não haver negros no Brazil com z. Si tiver algum tempinho me esclareça sobre os projetos arianizadores do DIP e o limite dos meus assuntos. É o milhor pretexto que tenho para esta alegria de ler suas palavras. (MEIRELES, 1996, p.294-295)

Esse artigo de Mário de Andrade é publicado no terceiro número da revista (TB, $\mathrm{n}^{\circ}$ 3, 1941). O texto está focado na descrição dos detalhes das pinturas da capela da família de Portinari, composta por apenas uma pequena sala, decorada pelo artista. Apresenta Portinari como um dos maiores artistas plásticos das Américas e informa que ele vive no Rio de Janeiro, mas retorna periodicamente a sua cidade natal, a pequena Brodowski paulista, de apenas dois mil habitantes, que, por receber a atenção de Portinari, é visitada também por escritores, artistas e críticos. Informa que embora Brodowski seja distante de centros como Rio de Janeiro e São Paulo, há excelente estrada de rodagem que a liga a essas grandes cidades, sendo acessível também pela ferrovia Mogiana. Afirma que a pequena cidade é uma das mais famosas atrações artísticas do Brasil e merece menção especial na literatura turística. $O$ artigo é ricamente ilustrado com reproduções fotográficas, em preto e branco, dos afrescos da capela.

No dia 25 de março de 1941, Cecília responde a Mário, explicando-se sobre a questão dos “irmãos em São Benedito", metonímia eufemística, utilizada por Mário em sua carta, para tratar da comunidade negra, e sobre os colaboradores que ela desejava para a revista:

Quanto à turma de S. Benedito, foi um custo, mas consegui metê-la nas ilustrações de uma coisa minha sobre Carnaval para o $2^{\circ} \mathrm{n}^{\circ}$. O chefe gosta mesmo é das senhoras sedosas que posam no Casino. Em todo caso, creio que admite a turma como "folclore". Ai! ajude-me nesta África!

[...] Depois, quando V. quiser escrever uma coisinha, não é preciso que eu lhe peça mais: mande sempre. V. sabe como revista come artigo. E eu não queria que houvesse invasão de colaboradores. V. me entende, não é? (MEIRELES, 1996, p.295)

A "coisa minha" a que se refere Cecília Meireles no $2^{\circ}$ número da revista, de 1941, é um artigo intitulado "Carnaval no Rio", em que descreve adereços, desfiles, danças, brincadeiras e músicas dos blocos do Carnaval do 
Rio de Janeiro. Trata também do Carnaval de "antigamente", o retratado por Jean Debret e o que ela imaginava a partir das histórias contadas pela avó. Aborda o Entrudo do século XVII e de como este, pouco a pouco, foi sendo sucedido pelo Carnaval propriamente dito, cujas manifestações envolvem brincadeiras com confetes, bisnagas, serpentinas e línguas-de-sogra. Menciona ainda a assimilação de costumes italianos pelo Carnaval carioca, como as personagens do Pierrot, da Colombina e do Arlequim. O texto é ricamente ilustrado com fotografias de pessoas fantasiadas e muitos jovens, principalmente moças brancas, divertindo-se em automóveis ou a pé em largas avenidas do Rio de Janeiro. As fotos, com legendas, mostram também bailes de salão, fantasias de palhaços ao estilo europeu, um Romeu, uma Marlene Dietrich, uma fantasia feminina inspirada em um quadro de Velasquez, uma havaiana, algumas baianas brancas, um Mephisto e uma Margaret, pessoas sentadas tomando champanhe em mesas de baile de salão. Trata também dos cordões e dos "ranchos", como sendo um tipo de representação dramática, resultante da mistura de costumes negros com reis e rainhas europeias; comenta um deles, baseado nas Walkirias, de Wagner, e aí consegue incluir fotografias de personagens que são magras negras vestidas de fadas da mitologia germânica. Aborda ainda os desfiles de rua do Rio de Janeiro e o rei Momo, como representação de um rei latino da diversão.

Em carta datada de janeiro de 1942, Cecília pede a Mário que lhe envie um texto sobre música carnavalesca para o número de fevereiro da Travel in Brazil. Afirma que a revista está melhorando, "já se pode falar de assuntos de todas as 'cores' - preto, branco, marrom, etc.” (MEIRELES, 1996, p.296)

De fato, se observarmos, no primeiro número de 1942, encontramos dois textos que tratam de artes populares. R. Magalhães Jr. escreve sobre "Jangadas e Jangadeiros", apresentando a jangada nordestina, suas funções nas comunidades locais de pescadores, compara-a com as embarcações feitas pelos nativos do Pacífico Sul. Em texto não assinado, mas de provável autoria de Cecília Meireles, intitulado "Bonecas Brasileiras", ricamente ilustrado, a autora apresenta as bonecas baianas, "feitas em casa pela criada ou pela Avó, de uma velha meia preta, com um bordado em linha branca para fazer os olhos, a boca bordada com linha vermelha e o vestido no estilo tradicional das negras baianas" (TB, $N^{\circ} 1,1942$, p. 19). Em seguida, trata das bonecas do Estado do Pará, que mimetizam atividades cotidianas da região Norte, e aí insere uma série de fotografias que poderiam contar a História do Brasil:

Em uma pequena coleção é possível sintetizar a História Brasileira. Primeiro eram os Índios, com seus arcos e flechas, serpentes e penas. Depois vieram os Europeus brancos, para arar o solo, criar ranchos e explorar esse imenso território. Finalmente, os sorridentes negros chegaram, a cujas mãos todos os trabalhos domésticos foram destinados; cozinhar, lavar etc. (TB, $\mathrm{n}^{\circ}$ 1, 1942, p.19)

Em outra carta, datada de 18 de agosto de 1942, Cecília Meireles volta a solicitar artigos ilustrados a Mário de Andrade, sobre 
pinturas em tetos de igrejas, conforme ele havia sugerido em carta anterior. Cecília conclui seu texto com a seguinte nota: "Tenha cuidado com o material humano que apareça em alguma foto: voltamos ao regime exclusivamente ariano." (MEIRELES, 1996, p. 300). Como grotesca materialização desse regime, encontramos no último número da revista (TB, $\mathrm{n}^{\circ} 4$, 1942), o artigo "A Escola Nacional de Educação Física do Brasil”, assinado por J. Moreira de Souza, em que esse autor aborda a criação por Getúlio Vargas, pelo Decreto-Lei 1212, de 17 de abril de 1939, da Escola Nacional de Educação Física e Esportes, iniciativa justificada como sendo de vital necessidade humana e patriótica. Fotos estetizadas de rapazes fazendo ginástica na praia, compatíveis, segundo o autor, com a dignidade e a beleza da vida, lembram a exaltação do corpo, da ginástica e da disciplina tão característica dos regimes totalitários então vigentes na Alemanha e na Itália.

Assim, temos, por um lado, o contexto de uma Europa devastada pela II Guerra Mundial, por cujos regimes totalitários e racistas da Alemanha e da Itália o ditador brasileiro, Getúlio Vargas, mostrava ainda ter simpatias. Por outro, uma população que cada vez mais se enriquecia nos Estados Unidos e demandava novos serviços, entre os quais o turismo, para quem a linha editorial da revista, evidentemente por determinações superiores, como bem notamos na correspondência entre Cecília e Mário, opta por apresentar um Brasil embranquecido, marcado pela influência europeia e em pleno desenvolvimento em direção à Modernidade. Claro, como vimos, a poeta submetia-se criticamente a essa linha racista, afinal, ainda entre 1926 e 1934 havia feito desenhos de baianas e de tradições afrobrasileiras, com os quais ilustrou a conferência "Batuque, Samba e Macumba", que pronunciou em Lisboa, em 1934, e, no ano seguinte, foi editada em Portugal, como separata da revista Mundo Português. Conferência em que exalta as qualidades do negro, quando o paradigma do Modernismo brasileiro era a valorização do mestiço. Nesse livro-conferência, editado no Brasil pela Funarte em 1983 e pela Martins Fontes em 2003, esclarece, por exemplo, que o batuque e o samba são restos de ritual primitivo. "O batuque provirá do ritual de adestramento masculino para as lides de guerra", do qual teria derivado, no Brasil, a escola de capoeiragem (MEIRELES, 2003, p.54-55).

Se o batuque é o resto de um ritual de guerra, o samba é resto de um ritual de casamento:

No brinquedo também está de certo modo compreendido o samba - que é, naturalmente, sobrevivência de ritual de casamento, dado o ar contidamente erótico que conserva. Como o batuque, é uma dança ímpar, executada no meio de uma roda, que igualmente canta, bate palmas e toca tambores, pandeiros, cuícas, caixinhas e chocalhos. (MEIRELES, 2003, p.58)

Porém, na Travel in Brazil, o alvo é o turista norte-americano e é sob encomenda para esse público asséptico que a nossa poeta é encarregada de editar a revista e procurará fazê-lo da maneira mais coerente possível com sua própria visão de mundo. Ao mostrar aspectos da cultura e da paisagem 
brasileiras a ênfase terá de recair sobre a herança europeia, no entanto, Cecília buscará brechas para contornar as normas do DIP e mostrar uma maior complexidade étnica, social e cultural de nosso país. Assim, logo no primeiro número da revista, editado em 1941, nomeação e fundação do país tornam-se objeto dos dois primeiros artigos. A própria Cecília Meireles tece a história das referências do nome "Brasil", presente desde relatos de Marco Polo sobre o Oriente, passando por novelas de cavalaria até convergir para a história da chegada dos portugueses ao Novo Mundo. Esse artigo se complementa com o de autoria de Sérgio Buarque de Hollanda, em que esse historiador polemiza sobre o ano de 1500 como marco do Descobrimento do Brasil, pois o país faz parte da América, descoberta oito anos antes. A partir dessa polêmica de integração pan-americana, tece um panorama da História do Brasil que chega até a Proclamação da República e introduz o tema da miscigenação racial e cultural do branco com o índio e o negro, assim como, no artigo anterior, ao nome e à fundação europeus que herdamos, Cecília integra a natureza tropical com referências à flora, à fauna e à paisagem litorânea.

Há ainda, nesse primeiro número de 1941, dois artigos que tratam do sincretismo cultural no Brasil. Como já mencionado, o de Mário de Andrade, em "Música Brasileira”, aborda as formas híbridas da música brasileira, e o de Nóbrega da Cunha, que trata das famílias rendeiras no Brasil. Costume este que teria chegado aqui com os franceses que vieram fundar a França Antártica em 1567. A atividade das rendas recebeu, no século XVII, influências dos holandeses em Pernambuco. Destaca Fortaleza como a capital brasileira da renda e, como colecionador desse artefato, Nóbrega da Cunha considera difícil distinguir a renda brasileira da europeia.

A ênfase na herança europeia e na integração de novos imigrantes à realidade nacional evidencia-se também, por exemplo, no artigo assinado por Florência (TB, $n^{\circ} 3,1941$ ), em que apresenta imigrantes portugueses e italianos substituindo os antigos escravos como vendedores ambulantes no Rio de Janeiro e introduzindo novos produtos nesse comércio. Nota-se ainda uma frequência de textos que tratam da cidade de Petrópolis, de seu Museu Imperial e da figura do Imperador Pedro II, como homem europeizado e moderno para o seu tempo, o que distinguiria o Brasil por ser herdeiro de uma cultura aristocrática. Entre esses artigos, destaca-se o da própria Cecília Meireles (TB, $\mathrm{n}^{\circ} 4$, 1941), em que aborda o Palácio do Imperador, transformado no Museu Imperial de Petrópolis. Esse museu, em vias de criação, contaria com a reunião dos objetos imperiais dispersos entre os órgãos públicos e as coleções particulares e teria suas salas reconstituídas com base em documentação da época. Informa que a cidade serrana era o refúgio favorito do monarca. Descreve aposentos e objetos do Museu. Entre os detalhes decorativos, como cristais, porcelanas de Sèvres, além de móveis europeus e presentes de amigos estrangeiros, inclusive um relógio dado a Pedro II por Napoleão III, inclui, não gratuitamente, a fotografia do Imperador, ainda bebê, no colo de uma mucama negra. Conclui seu texto sobre o Museu Imperial, remetendo-se à 
dicotomia do turista passante e do turista estudioso: "para alguns, oferece-se como uma ótima oportunidade turística e para outros como uma oportunidade esplêndida para reflexão e uma verdadeira fonte de estudos."

Há dois ricos textos, na Travel in Brazil, que tratam de Ouro Preto. O primeiro é de Manuel Bandeira, intitulado "Ouro Preto, a Antiga Villa Rica” (TB, $n^{\circ} 4$, 1941). Bandeira tece uma síntese da história de Ouro Preto, da mineração e de seu enriquecimento no século XVIII, prosperidade que se estendeu a São João Del Rei, Mariana e Diamantina, até a decadência, empobrecimento e quase abandono da antiga Vila Rica no século XIX, que, por essas mesmas condições, logrou preservar a arquitetura do período áureo. Bandeira também faz referência ao tombamento de Ouro Preto como Monumento Nacional pelo Presidente Vargas. Em segui$\mathrm{da}$, apresenta impressões sobre as igrejas da cidade, as obras de Antônio Francisco Lisboa, o Aleijadinho, de Manuel Costa Ataíde e do grupo de poetas que deu origem à "Escola de Minas". Narra sumariamente a história de Chico Rei, que com trabalho e inteligência comprou a própria liberdade e a do filho, a de outros escravos e uma mina. Termina por referir-se ao movimento da Inconfidência e a escritos de viajantes estrangeiros que passaram pela cidade no século XIX, especificamente de John Lucock e Richard Francis Burton. Seu texto é ilustrado com rico material fotográfico que mostra a Ponte Antônio Dias, a Igreja de São Francisco, a Torre do Relógio de Santa Ifigênia, a Fonte de Marília, a Igreja do Rosário, o Museu da Inconfidência, a Igreja de Antônio Dias, entre outros monumentos de Ouro Preto. A crônica "De Vila Rica de Albuquerque a Ouro Preto dos Estudantes”, compilada na coletânea Crônicas da Província do Brasil, de Bandeira (2006), pode ser considerada uma versão ampliada do texto publicado na Travel in Brazil.

No último número da Travel in Brazil $\left(n^{\circ} 4,1942\right)$, Cecília Meireles insere um longo artigo intitulado "Semana Santa em Ouro Preto". Como Bandeira, Cecília também abre seu texto informando que por iniciativa do Governo Vargas, Ouro Preto foi convertida em uma cidade-museu, monumento nacional. Proibiu-se qualquer construção nova ou demolição que desfigurassem sua beleza e valor histórico. Essa medida poderia tornar Ouro Preto inacessível aos turistas, porque lá não há hotéis modernos. Cecília informa haver um hotel em construção e que os visitantes podem se hospedar em casas de família, fiéis aos costumes da hospitalidade brasileira. Trata da Inconfidência Mineira e do poeta Gonzaga. Em seguida, para introduzir o tema da Semana Santa em Ouro Preto, traz à mente do leitor os famosos festejos religiosos de Oberammergau e Sevilha. Mas, diferentemente dessas cidades, a religiosa Ouro Preto permanece "fechada em sua reticência grave, não foi até agora devorada pelos olhos curiosos, que, procurando sensações, viajam por todas as terras e os mares do mundo" (TB, $\mathrm{n}^{\circ} 4$, 1942, p.16-17). Em seguida, passa a descrever minuciosamente o cenário (igrejas, praças, escadarias, ruas) em que se encenam os episódios da Semana Santa. Apresenta as multidões compactas em janelas, balcões, muros e calçadas, que afluem de todas as 
partes para assistir à procissão. Descreve dia a dia, detalhadamente, os ritos que ocorrem desde o Domingo de Ramos até o Domingo de Páscoa, em texto ricamente ilustrado por material fotográfico, que evidencia os traços da arquitetura e da escultura do Barroco mineiro. Minuciosa descrição da Semana Santa em Ouro Preto em que se entrevê a assimilação pela cultura popular brasileira de traços das tradições europeias.

Além de elementos mais propriamente culturais acentuados pelos textos - como a arquitetura, a escultura, a música, as rendas, as festas populares - e que nos aproximariam das tradições europeias, mas, quase sempre, modalizadas, por nuances de hibridismo étnico e cultural, a descrição de paisagens brasileiras, em alguns textos, sugere a Europa Central, particularmente a Suíça, como as serras e os vales fluminenses, com suas pequenas estâncias turísticas. Destaca-se também a cidade termal de Poços de Caldas, cujas fotografias mostram amplos saguões de hotéis decorados com esculturas ao estilo clássico greco-latino e espaços abertos para a prática de hipismo e golfe. Ao final da reportagem (TB, $\left.{ }^{\circ} 1,1942\right)$, não assinada, há uma tabela com o tempo de viagem entre Poços de Caldas e Rio de Janeiro, São Paulo e Belo Horizonte, por estrada de rodagem, ferrovia e via aérea.

Assim, devido a seus traços culturais e paisagísticos, o Brasil poderia se oferecer a americanos endinheirados, em busca de lazer ou negócios, como lugar substituto da Europa em guerra. Para isso, convinha enfatizar também elementos de Modernidade, que envolviam facilidades de deslocamento, estrutura de hospitalidade e lazer: os parques de São Paulo, as estradas que levavam de São Paulo a Santos e do Rio de Janeiro a Petrópolis, as possibilidades de se viajar a Poços de Caldas, as brincadeiras do carnaval carioca ocorrendo em salóes requintados ou em automóveis sobre largas avenidas, os bares, restaurantes e cassinos da orla carioca, ou ainda a beleza da paisagem da Estrada de Ferro da Graciosa, prodígio da engenharia nacional, ligando o porto de Paranaguá a Curitiba, que Tasso da Silveira apresenta no artigo "Curitiba e a Estrada de Ferro do Paraná" (TB, nº 2, 1941).

Nesse artigo, o poeta paranaense Tasso da Silveira apresenta o Estado do Paraná por meio de uma referência ao viajante francês Auguste de Saint-Hilaire, que denominou os Campos Gerais do Paraná, na viagem que realizou à Comarca de Curitiba em 1820, de "paraíso brasileiro". Em seguida, trata da moderna engenharia que produziu a Estrada da Graciosa em uma terra montanhosa, construída em 1885 e correndo em paralelo com a estrada de rodagem. A partir daí, o poeta passa a descrever a paisagem, como se estivesse em viagem pela ferrovia entre Paranaguá e Curitiba. Descrições que sugerem o viajante ceciliano, tal como a poeta o caracteriza em crônicas dos anos de 1940 e 1950, como em "Roma, Turistas e Viajantes", de 1953. Observemos um trecho em que Tasso da Silveira descreve a paisagem nos primeiros quilômetros de viagem a partir de Paranaguá, criando imagens alusivas ao Paraíso Terrestre:

De fato, após os primeiros quilômetros desse trajeto, entre mangueiras, 
bananeiras e palmeiras no trecho costeiro, a dificuldade da subida começa. O trem assobia sob o tremendo esforço, por conta da forte declividade. O primeiro túnel anuncia a luta entre Hércules e a montanha. $O$ trem atravessa-a, mergulhado em escuridão e fumaça, e isso torna a travessia cansativa. Mas, por outro lado, quando reaparece luz, nossos olhos encontram um prodígio, um mundo totalmente inesperado de infinita frescura, como era ele quando apenas saía das mãos de Deus. Um vale profundo, entre paredes cobertas de musgo e altos picos delineados contra o céu puro e elevado. Cachoeiras, fontes idílicas, névoas de leveza etérea, troncos e copas das árvores de pinheiros, vistas como em miniatura na parte inferior dos abismos, cipós, uma floração primaveril completa. E em nossas almas temos a sensação de que toda a vida renasce com um novo fôlego de uma nova criação, livre de poeira, de tédio, do cansaço, com a mesma inocência transcendente e beleza que a Terra deve ter tido quando ela ainda não fora maculada pela ganância insana e pelas paixões. (SILVEIRA. TB, $\mathrm{n}^{\circ} 2$, 1941, p.31)

A chegada desse contemplador a Curitiba é anunciada pelos milhares de lâmpadas elétricas que sugerem a modernidade dessa cidade, à época, com cerca de 150 mil habitantes: "E, quando a noite começa a esconder a paisagem dos olhos ávidos, longe Curitiba se anuncia pela pulsação de milhares e milhares de lâmpadas elétricas, brilhando na escuridão" (SILVEIRA. TB, ${ }^{\circ}$ 2, 1941, p.31).
Curitiba surge na imaginação do leitor a partir de imagens de seus modernos meios de transporte, como ônibus e automóveis, seus clubes, bairros arborizados, centro comercial, indústria moveleira, hospitais, programas de assistência social, que levam o descritor a anunciá-la como uma cidade sem mendigos. Esse florescente desenvolvimento da cidade ainda jovem surge envolvido pela aura da natureza exuberante: o frescor do clima, a vegetação de coníferas, as flores e os frutos:

Antes de prosseguir, é preciso dizer que Curitiba foi construída em meio a uma região única na América, com clima e aspecto mediterrâneos: o planalto do Paraná. As árvores, as flores, os frutos de Curitiba são as da costa do mar do sul da Europa clássica. As árvores são as das espécies de coníferas: pinheiros, cedros, ciprestes, abetos, com coroas altas, de formas góticas. As flores são rosas, madressilvas, violetas, camélias, margaridas, jasmins, sempre-vivas, cobrindo as cercas dos jardins e decorando os jardins públicos. Os frutos que crescem em Curitiba são uvas, pêssegos, peras, maçãs, ameixas, marmelos transplantados sem dúvida - e "gabirobas", "pitangas" e outras ácidas frutas nativas. Tudo isso dá à cidade - que é realmente nova - um aspecto especial de permanente adolescência, uma vez que é cercada por montanhas, que são tão azuis a ponto de se tornarem diáfanas, e sobre elas se curva o mais suave e mais leve dos céus brasileiros, um céu que tantos poetas e pintores de renome - e entre os primeiros o ilustre poeta Alberto de Oliveira - têm celebrado em 
poemas e em telas. (SILVEIRA. TB, $\mathrm{n}^{\circ}$ 2, 1941, p.32)

Caracterização da região de Curitiba filtrada pela descrição de um olhar europeu. Observemos como Auguste de SaintHilaire descreve e avalia a natureza e as árvores frutíferas que encontra na região dos Campos Gerais, em um fragmento de Viagem à Comarca de Curitiba, em 1820:

Nessa bela região não cultivam somente o nosso linho e os nossos cereais; plantam também, com bons resultados, quase todas as nossas árvores frutíferas. Infelizmente, como já tive ensejo de dizer a época das grandes chuvas coincide com a em que as frutas começam a amadurecer e, por isso, elas nunca ou quase nunca chegam a sazonar inteiramente. Devemos, entretanto, excetuar os figos, que, como os de Minas, são excelentes. Saboreei também em fevereiro ótimas uvas brancas; mas, em geral, essas frutas, como as outras, não amadurecem completamente. $O$ calor intenso não prejudica a vinha, mas é necessário que à temperatura sensivelmente elevada não se alie excessiva umidade: as uvas que amadurecem em Goiás, à época da seca, apenas refrescadas pelo orvalho, são deliciosas; as dos Campos Gerais são medíocres. O pessegueiro já se acha aclimatado nessa região e chegam a utilizá-lo na feitura de cercas vivas. Como em São Paulo, dentre as árvores frutíferas, é a primeira que floresce; anualmente, no mês de agosto, caem-lhe as folhas, imediatamente depois cobre-se de flores e produz enorme quantidade de frutos que começam a ser apanhados em fevereiro.
As cerejeiras e ameixeiras frutificam desde janeiro, e nos primeiros dias de fevereiro ainda comi ameixas que achei ótimas, a despeito da espécie a que pertenciam. Inicia-se a colheita das maçãs e dos marmelos em fevereiro e continua-se a apanhá-los até abril. Disseram-me que as pereiras dão bons frutos. Quanto às bananeiras, muito embora se possa considerar a vila de Itapeva o ponto extremo em que no planalto de São Paulo se cultiva essa musácea, conseguem-se ainda ótimas bananas nos Campos Gerais, desde que se escolham sítios favoráveis e se dispensem à planta cuidados especiais. (SAINT-HILAIRE, 1964, p.30-31)

Em seguida, surge a afirmação de SaintHilaire, a partir de cuja referência Tasso da Silveira iniciou seu artigo: "Do que acabo de dizer, pode-se concluir que não exagero em dar aos Campos Gerais a denominação de Paraíso terrestre do Brasil." (SAINTHILAIRE, 1964, p.31)

É sob o filtro de um olhar europeu que ressalta semelhanças entre as terras paranaenses e a Europa, que Tasso da Silveira se dirige ao seu possível leitor. Em seu artigo, encontramos três movimentos recorrentes nos textos da Travel in Brazil: acentuar a modernidade brasileira, descrever as belezas naturais que o turista estrangeiro poderá aqui encontrar, usufruindo do conforto dos aspectos da urbanidade moderna, além de marcar traços de nossa natureza e cultura que assimilaram elementos europeus.

Um aspecto da cultura paranaense de menor apelo ao turismo de massas é focalizado no artigo "A Casa do 'Caboclo”, (TB, 
$\mathrm{n}^{\circ} 3$, 1941). Nele, o arquiteto Ângelo Alberto Murgel contrasta o patrimônio em granito e mármore deixado pelas civilizações antigas, que nos permitem fazer suposições sobre como viviam esses povos, com a vida cotidiana e anônima das pessoas comuns, que poderiam ser conhecidas por suas habitações, se essas resistissem ao tempo. Em seguida, trata das casas populares de diferentes regiões e estados brasileiros. Considera que as casas do interior de Santa Catarina, Paraná e norte do Rio Grande do Sul têm em comum o fato de serem feitas de madeira com bom acabamento, pois há muitas serrarias nessa região. Murgel lembra que esse tipo de construção em madeira é bem conhecido do povo norte-americano, mas, considera, "percebemos que elas não só têm um caráter essencialmente regional, mas os traços presentes de outros povos de acordo com o elemento imigrante predominante na localidade" (TB, $\mathrm{n}^{0} 3$, 1941, p. 25). Dessa forma, aproxima a paisagem de partes do Sul do Brasil de certo aspecto da paisagem humana do Sul dos Estados Unidos. Cria, assim, um elemento tranquilizador para o turista, que aqui poderia encontrar aspectos conhecidos de sua própria cultura e, ao mesmo tempo, alimenta sua curiosidade, à medida que acentua as diferenças, dadas pelas condições locais e pela incorporação de elementos dos imigrantes.

Merecem destaque três textos, de autores estrangeiros, que testemunham sobre o País. O primeiro deles intitula-se "Caçando no Mato Grosso" (TB, $\mathrm{n}^{\circ} 2,1941$ ), escrito pelo norte-americano John Adams. Outro, de autoria do recém-chegado imigrante húngaro Paulo Rónai (TB, $n^{\circ} 4,1941$ ), intitulado
"Impressões de um Europeu do Rio em 1941". E o texto de Henry Albert Phillips, intitulado "Asas sobre o Brasil" (TB, $\left.\mathrm{n}^{\circ} 1,1942\right)$, comecemos por este, que inclui também observações sobre o Paraná.

O viajante norte-americano, Henry Albert Phillips, redige suas impressões após ter percorrido o país de Norte a Sul em avião, viaja durante oito dias, além de outros quinze de estada em diferentes locais do Brasil. Exalta a possibilidade, por meio da viagem aérea, de ver grande parte do País sem ter de passar meses viajando. Inicia seu percurso em um hidroavião Clipper, de Miami a Belém, "cidade que contata os mares estrangeiros do mundo todo e é a porta de entrada para se deslocar pelo incrível mar de águas doces do interior" (TB, ${ }^{\circ} 1,1942$, p.23). Depois, surpreende-se com a existência de São Luiz, próspera cidade marítima de que nunca tinha ouvido falar, e, do alto, aprecia as cestas com produtos tropicais na baía de São Marcos. Encanta-se com o sal branco, brilhando como joias, próximo a Natal e Fortaleza; deslumbra-se com o verdor de Recife, a Capital do Coco, que afirma ser metade de uma Filadélfia. Salvador, segundo Phillips, é a cidade que melhor preserva a arquitetura europeia. Observemos a descrição que faz do Rio de Janeiro, em voo proveniente de Salvador, próximo de pousar no aeroporto Santos Dumont, que considera ser o mais belo do mundo:

O próximo voo nos leva em menos de 1.000 milhas ao mais belo aeroporto do mundo. O Rio de Janeiro deve ser visto do ar para ser minunciosamente apreciado. De cima nós vimos todas suas maravilhas de um só relance 
panorâmico. As pedras fantásticas ascendendo do mar como leões curiosos, o Pão de Açúcar com um carro suspenso no meio do ar em cabos invisíveis a meio caminho além do abismo que o separa da pedra de apoio na montanha tão querida pelos turistas. O Cristo de 100 pés no Corcovado, comumente aparece no alto na manhã ou na névoa do anoitecer, parece estar com os braços abertos, misticamente sozinho entre as nuvens, invisível no momento para o mundo abaixo. As lagoas espalham suas águas interiores em vieiras graciosas com praias de areia branca, às vezes com parques verdejantes descendo em direção às bordas das águas. Copacabana como uma concha parada na baía interna, com seus hotéis modernos e apartamentos surgindo como carbúnculos em um cenário barroco. As mais de centenas de ilhas dispostas como jardins exuberantes caídos das nuvens em meio a um plácido oceano. A Academia Naval, as balsas, grandes e pequenos navios. Finalmente a Capital; tão única, tão inconvencional, tão verde com suas árvores, se aninhando no fundo do círculo de morros, o mais próximo se pode escalar e alcançar os promontórios mais distantes a caminho da agradável Estrada da Tijuca. A joia mais brilhante no mais amável cenário do continente. (PHILLIPS. TB, $\mathrm{n}^{\circ} 1,1942$, p.28-29)

O destino seguinte é São Paulo, que diz ser a cidade irmã de Nova Iorque. Depois, descobre a existência de Porto Alegre e Curitiba. Revela a surpresa de encontrar dois arranha-céus de 16 andares na rua principal de Curitiba. Em seguida viaja até as Cataratas do Iguaçu:

De Curitiba, fizemos um pequeno desvio para uma excursão às Cataratas do Iguaçu e encontramos uma das quatro cachoeiras mais maravilhosas do mundo. As Cataratas do Iguaçu não são tão altas ou poderosas como as do Niágara, mas a seu modo elas são majestosas e pitorescas. (PHILLIPS. TB, $\mathrm{n}^{\circ} 1,1942$, p.30)

Depois da passagem pelo Sul do Brasil, retorna a Belém e paira sobre o rio Amazonas em um hidroavião, pousando em comunidades ribeirinhas e em Manaus, a cidade, em meio à floresta, de 100 mil habitantes, com um teatro de milhão de dólares e passeio público feito com mármore de Carrara. Surpreende nesse texto, de 1942, o lirismo da inusitada perspectiva aérea a partir da qual o viajante vê o Brasil. Lirismo este que também encontramos em crônicas de viagem de Cecília Meireles a partir da década de 1950, como "O Avião" e "Madrugada no Ar", entre outras, em que a poeta se detém na descrição dos desenhos das paisagens aéreas, de voláteis nuvens, e terrestres vistas do alto, seja da natureza, seja de cidades, imagens que se misturam às eruditas referências e à efabulação da poeta. Olhar ceciliano que encontra correspondências em outros fragmentos do texto de Phillips, como: "Mas toda essa viagem parece uma jornada encantada em cima de um Tapete Mágico". Phillips encerra sua viagem retomando o bordão de Stephan Zweig sobre o Brasil: "O viajante que faz essa jornada estará fazendo mais do que uma mera viagem de avião, ele estará vendo de 
cima a baixo, dentro e fora, o País do Futuro" (PHILIPPS. TB, $\mathrm{n}^{\circ} 1,1942, \mathrm{p} .32$ ).

Entretanto, se ao turista americano agradava uma aventura mais "selvagem" pelo Brasil, ou melhor, encontrar um país em "estado de natureza", há o relato de John Adams (TB, $n^{\circ} 2,1941$ ), que com duas mulheres adentra o interior de Mato Grosso para um safari, longa reportagem ilustrada com fotos de acampamento, churrasco, animais de caça, aves e peixes da região. Nessa mesma edição, há breve informe em que se anuncia a intenção do Presidente Vargas em ali também introduzir a Modernidade, com a construção de uma estrada de ferro que ligaria o Brasil à Bolívia.

O imigrante europeu Paulo Rónai (TB, $\mathrm{n}^{\circ} 4,1941$ ), chegado havia apenas dois meses ao Brasil, descreve a visão de esplendor que teve do Rio de Janeiro, depois de deixar uma Europa empobrecida e devastada pela guerra. Vem informado por variadas leituras sobre o país, entre as quais menciona o escritor judeu-austríaco Stephan Zweig, que escolheu a região serrana fluminense para ser sua (última) morada (Zweig se suicidou no ano seguinte à publicação do artigo de Rónai). A Zweig devemos o agora desgastado bordão "Brasil, País do futuro" (mas que ainda nos assombra...).

Em texto lírico e sincero, Paulo Rónai descreve as belezas naturais e riquezas culturais do Rio de Janeiro, que associa a reminiscências de sua Europa de origem. O murmúrio do mar verde-azulado, visto a partir de uma cafeteria da Avenida Atlântica, recorda a praia de Ostende. A vista do $10^{\circ}$ andar de um prédio na Avenida Rio Branco, com seu intenso fluxo de carros de passeio, táxis e ônibus, com o brilho da luz do sol refletida nos para-brisas, sugere Paris vista do topo do Arco do Triunfo. O Largo do Boticário remete à velha Bruges de Flandres. A Floresta da Tijuca, ele associa ao Vale Fresca, "mágica floresta próxima a Budapeste". A Ilha de Paquetá, onde os amantes se beijam sob a sombra das árvores, lembra a Ilha de Santa Margarida, no Danúbio. Numa livraria da rua do Ouvidor - cujo interior é mostrado com fotografias em que pessoas, quase todas brancas e sempre vestidas à europeia, folheiam livros diante de bancadas e grandes estantes - encontra preciosas obras banidas do Velho Continente pelo monstro nazista. Nas ruas, sente as fragrâncias não mais destiladas na Europa. Termina o belo texto agradecendo ao Rio de Janeiro:

[...] por nos fazer perceber o milagre da união do antigo e do novo; o conhecido e o ignorado; a revelação e a saudade. Agradecemos por ter preparado para nós as riquezas inesgotáveis do Novo Continente e ao mesmo tempo por ter preservado tanto dos tesouros sentimentais e intelectuais da nossa Europa aflita. (RÓNAI. TB, nº 4, 1941, p.19)

A diversidade temática da Travel in Brazil parece revelar que Cecília Meireles devia se debater com a tentativa oficial de fazer da revista um canal de divulgação no exterior não somente de um Brasil dotado de uma natureza exuberante, como também de um povo hospitaleiro e europeizado, que se inseria rapidamente na modernidade, como mostravam seu urbanismo, suas estradas, seus hotéis e as facilidades de 
viagens aéreas pelo país. A ideia a divulgar parecia ser, como mais de um estrangeiro não ingênuo afirmara, o Brasil é o "País do Futuro". Cecília Meireles, que na década de 1930, houvera confrontado o Governo Vargas devido ao Decreto-Lei que instituía o ensino religioso no Brasil, e, por isso, fora vítima de represálias, passa a editar a revista de turismo para o DIP. Ela amava viajar, amava a viagem como uma forma de conhecimento daquilo que está além da própria "aldeia", e por isso buscava, no espaço do "inimigo", brechas para mostrar uma maior complexidade cultural do Brasil. Como vimos, na correspondência com Mário de Andrade, ela lhe solicitava artigos, para tentar evitar "invasão de colaboradores". Edita textos ricos em informações e ilustrações para viajantes que não são apenas "passantes", ou turistas, como se constata em textos de Manuel Bandeira, Paulo Rónai, Sérgio Buarque de Hollanda e nos muitos textos, assinados ou não, de autoria da própria Cecília. É interessante notar que Cecília Meireles (TB, $\mathrm{n}^{\circ} 1,1942$ ), como mencionamos, apresenta as bonecas artesanais como um dos traços mais pitorescos do folclore dos povos. Ao editar esse texto na sequência do que apresenta um Brasil europeizado em Poços de Caldas, a poeta, sutilmente, consegue mostrar as contradições de uma realidade nacional mais complexa que aquela que o discurso turístico e as intenções políticas do DIP pretendiam divulgar.

Em síntese, podemos reconhecer alguns elementos recorrentes nos textos da Travel in Brazil: os aspectos da modernidade do Brasil; referências às belezas naturais do país, embora este ainda não apareça como paraíso balneário de praias tropicais; traços de assimilação de elementos europeus à natureza e à cultura nacionais; além da propaganda do Governo Vargas por meio de feitos que estariam conduzindo ao desenvolvimento do País ou à preservação de seu Patrimônio Histórico. Como marcas do perfil ceciliano, encontramos de modo bastante recorrente nos textos da revista, uma função de leitor que seria um potencial viajante contemplativo e informado, que se distinguiria do turista de massas; o cosmopolitismo, mas também a valorização de aspectos das culturas populares, pois lembremos que Cecília foi uma militante dos estudos sobre o folclore.

\section{REFERÊNCIAS:}

BANDEIRA, Manuel. Crônicas da Província do Brasil. Organização, Prefácio e Notas de Júlio Castañon Guimarães. São Paulo: Cosac Naify, 2006.

CRISTÓVÃO, Fernando (Org.). Condicionantes Culturais da Literatura de Viagens. Coimbra: Almedina, 2002.

ENZENSBERGER, Hans Magnus. Com Raiva e Paciência. Tradução de Lya Luft. Rio de Janeiro: Paz e Terra, 1985.

GOETHE, J. W. Viagem à Itália 1786-1788. Tradução de Sérgio Tellaroli. São Paulo: Companhia das Letras, 1999.

MeIRELES, Cecília. Cecília e Mário. Rio de Janeiro: Nova Fronteira, 1996.

Crônicas de Viagem 1. Rio de Janeiro: Nova Fronteira, 1998.

Crônicas de Viagem 2. Rio de Janeiro: Nova Fronteira, 1999.

. Crônicas de Educação 4. Rio de Janeiro: Nova Fronteira, 2001. 
Batuque, Samba e Macumba. São

Paulo: Martins Fontes, 2003.

MONTAIGNE, Michel de. Diario de Viaje a Italia, por Suiza y Alemania. Traducción de Jaume Casals Pons. Barcelona: Ediciones Peninsula, 1986.

SAINT-HILAIRE, Auguste de. Viagem à Comarca de Curitiba (1820). Tradução de Carlos da Costa Pereira. São Paulo: Companhia Editora Nacional, 1964.

TRAVEL IN BRAZIL. Rio de Janeiro: The Press and Propagand Dept., Vol. 1, Nº 1, 1941.

. Rio de Janeiro: The Press and Propagand Dept., Vol. 1, Nº 2, 1941. . Rio de Janeiro: The Press and Propagand Dept., Vol. 1, Nº 3, 1941. . Rio de Janeiro: The Press and Propagand Dept., Vol. 1, Nº 4, 1941. . Rio de Janeiro: The Press and Propagand Dept., Vol. 2, Nº 1, 1942. . Rio de Janeiro: The Press and Propagand Dept., Vol. 2, Nº 2, 1942. . Rio de Janeiro: The Press and Propagand Dept., Vol. 2, No 4, 1942.

Recebido para publicação em 12 nov. 2015. Aceito para publicação em 15 jul. 2016. 